\title{
MECHANICAL PROCEDURES AS AN ENVIRON-MENTAL CONTROL ALTERNATIVELY WITH CHEMICALS ON LAND SNAILS AND SLUGS ON FRUIT TREES \\ Awad, M. H. ${ }^{*}$ and Y. Y. Ramaddan** \\ * Plant Protection Research Inst., A.R.C. \\ ${ }^{* *}$ Agric. Engineering Research Inst., A.R.C.
}

\begin{abstract}
Experimental studies were conducted under field conditions by adopting methods friendly with the environment at Damietta Governorate represented at Fareskure, ElZarka and Kafr Saad districts in addition to Sherbeen district in El-Dakahlia Governorate aimed to study the effect of tillage process and agricultural control of land snail of Monacha theba cartusiana (Muller) and slug deroceracas reticulatum (Muller) infecting some fruit trees such as lemon, orange, guava and peach, during winter and spring seasons, 2007/2008. The tillage process in each treatment was carried out into two levels according to the tillage depth of $15 \mathrm{~cm}$ and $25 \mathrm{~cm}$ in comparison with samples treated by Lanit 90 as molluscicides in each district. These three treatments were compared with others un- treated as a control to show the natural population of land snail and slug to tillage on $15 \mathrm{~cm}$ depth (site1), tillage on 25 $\mathrm{cm}$ depth (site 2) and plots which treated with Lanit 90 (site 3). The effect of tillage in site 2 was more effective than site 1 in most samples and was similar to site 3 and sometimes more effective on lemon and guava than in orange and peach, respectively.
\end{abstract}

\section{INTRODUCTION}

In recent years land snail and slugs became injurious pests attacking fields, vegetable crops and fruit trees causing serious economic damages not only in quantity but also in the quality of fruits such as lemon, orange, apple, peach, guava and pear by scraping the cortex layer of these fruits and encourage bacterial and fungal diseases on these fruits causes export rejecting. Land snails and slugs damage plant seeds, seedlings, underground tubers, leaves and fruit. Damage to seedlings often results in the death of the plant, which means major production losses.

In Egypt, such studies carried out on injurious snails to agriculture (Bishara et al, 1968), land snails which found at Alexandria caused economic damage and their control (El-Okda, 1979 and 1980) and also in Ismailia Governorate (El-Okda, 1984), Ecological and morphological studies on certain land snails at Sharkia governorate by (Ghamry et al, 1993) Seasonal fluctuation in population of the land snails in citrus trees in the northern reclaimed lands was carried out by (Hashem et al, 1993) economic importance of land snails on field crops, vegetables and fruits studied by (Kassab and Daoud, 1964) pest snails and slugs, biology and control reported by (Godan, 1983), Davison and (Chibas, 2006) studied the population structure of the mandarin snail species from Japan.

Slugs have involved from snails by losing or greatly reducing the external, hard, calcified shell, enabling them to live in small spaces such as in the soil. Slugs are better able than land snails to survive in cultivated fields. 
Since land snails and slugs and their principal natural enemies are soildwelling animals, cultivation can cause major changes to their numbers and behavior. These studies showed the influence of tillage systems on snails and slugs numbers and damage in fruit crops and the influence of tillage practices on the abundance of land snails and slugs and their natural enemies

These studies aimed to find the safety suitable and effective mean in controlling these land snails and slugs, where, it found on clover, fruits, leafy vegetables which injuries by chemical control that make these products unsuitable for human or animals, so, the suitable agricultural method was studied to remove the shelter of weeds and limiting the relative humidity in the soil under fruit trees and exposing the soil layers to the sun.

\section{MATERIALS AND METHODS}

\section{1- Seasonal fluctuations of land snail M. T. cartusiana and slug D. retculatum:}

Samples of M. T. cartusiana were obtained under field conditions from mixed gardens of fruits located in four districts, three of them were Fareskure, El-Zarka and Kafr Saad in Damietta Governorates while Sherbien district only in Dakahlia Governorate. Snails and slugs collected monthly from the soil under five marked trees for each crop of lemon, orange, guava and peach through two season of year (winter and spring) from November to the end of May as a way used by (Godan 1983 and Hashem et al 1993).

\section{2- Agricultural control by tillage process:}

Tillage process was divided into two treatments, the first one with depth of $15 \mathrm{~cm}$ one pass and collection after 3 days of tillage, the second treatment was perpendicular tilled twice to make two layers of soil with depth of $25 \mathrm{~cm}$ after 5 days from the first pass, snails and slugs collected after 3 days from the second pass.

\section{3- Lanit 90 (methomyl):}

Lanit 90 as recommended pesticides provided by Dupont company used in sort of spray as recommended dose used in land snail control in treatment 3 by five replicates for each collection of land snails and slugs after 3, 5, 10, 15 days

\section{4- Technique used:}

The plan of this work was divided into three divisions as follow snails and slugs under mixed fruit trees samples were taken from four districts with four types of fruit trees for each district, each tree sampled by five replicates for each one pass of $15 \mathrm{~cm}$ depth, second pass of $25 \mathrm{~cm}$ depth and lanit 90 treatments (Coate 2003).

Affected individuals were collected five days after one pass of tillage and three days after second pass of tillage and $3,5,10,15$ days after lanit 90 treatment. Reduction percentages were counted according to Hendreson and Tilton (1955) and corrected by Abott (1925). 


\section{RESULTS AND DISCUSSION}

\section{1- Seasonal fluctuations of land snail M. T. cartussiana and slug $D$. retculatum:}

The number of individuals shown in Table 1, indicates that the effect of temperature and relative humidity are very important on snail and slug population and on activity, so, it can be noticed that there is a difference between winter and spring seasons, where the low number was in winter season at Fareskure district. This population differed from a tree to another. The total number of snails and slugs in winter season in Fareskure were (70, 66,54 and 46) on guava, lemon, orange and finally in peach which shown the lowest number of individuals. While, in spring season at the same district, the number of individuals recorded the highest in guava trees (94) followed by orange (84), lemon (73) and the peach (60). It was noticed that the number of M. T. cartiaiana recorded highest number under orange and guava by the same of peach (58) individuals in spring more than the winter where recorded (30) individual under orange trees bur recorded (36) under guava trees also. It was noticed that the number of $D$. reticulatum showed the nearly similar number in winter and spring seasons (30/33), (24/26), (34/36) and (22/24) on lemon, orange, guava and peach in winter and spring seasons at Fareskure district, respectively. These values agree with that reported by Godan 1983, El-Okda 1982, and Hashim et al 1993.

At El-Zarka district of Damietta Governorate, the same fluctuation of snails and slugs were found but less than at Fareskure, in general, which recorded $(54,52,58$, and 40$)$ under lemon, orange, guava and peach respectively in winter season. While recorded $(65,72,74$, and 70$)$ in spring season with the same previous arrangements. It was remarked that the number of $M$. T. cartussiana was significantly differed from winter to spring only under orange, guava and peach which recorded (30/48), (34/48) and (20/44) at El-Zarka district throughout (winter/spring), respectively but under lemon trees the number of individual of $M$. T. carttusiana almost equal or the same number. This result may be due to the shelter of weeds from year to another under lemon trees and also the humus under these trees which mixed with soil and makes it warm all over the year, agreed with that reported by Godan 1983.

Data of Table 1 indicated the number of individuals varied at Sherbien district of Dakahlia Governorate as recorded (86, 84, 72 and 71) in spring season under lemon, guava, orange and peach respectively. While recorded $(64,56,46$ and 39$)$ under lemon, guava, orange and peach in winter season respectively. The highest number of $M$. T. cartusiana under guava (56) followed by lemon (52) while the same number of individuals found under orange and peach through spring season. Also in Kafr-Saad district it was found that the number of individuals differed from spring to winter seasons where recorded (72, 70, 69 and 68) under guava, lemon, orange and peach. The number of $M$. T. cartusiana increased twice in spring than in winter where recorded $(50,48,46$ and 46$)$ in spring while recorded $(26,24,28$ and 27 ) in winter on guava, orange, lemon and peach, respectively. 
From Table 1, data showed clear fluctuation of individuals affected by seasonal climatic factors and agree with that reported by Kassab and Dauood 1964, El-Okda 1979-1980 and Godan 1983. In general, it was observed that there were significant differences between individual of $M, T$. Cartusiana according to season while the number of slug had not affected by this factor or slightly affected.

Table 2. Effect of tillage process on Manacha T. Cartusiana and Deroceras reticulatum under fruit trees at Fareskoure, El-Zarka, and Kafr-Saad ditructs of Damietta Governorate and Sherbien district of El-Dakahlia Governorate.

Key words, Site $1=$ treated by tillage one way with depth of $15 \mathrm{~cm}$, Site $2=$ treated by tillage two way with depth of $25 \mathrm{~cm}$ and Site $3=$ treated by Lanit 90.

$$
\text { Re duction, \% }=\frac{\text { untreated }- \text { treated }}{\text { untreated }} \times 100 \text { and corrected by Abott, } 1925
$$

\section{2- Agricultural control by tillage process:}

The essential trend for this work was to protect the horticultural crops and avoid the dangerous effect of pesticides and protect our environment from chemical pollution. So, it is a must to try to find another method to produce products without chemicals.

The present work was conducted to control land snails and slugs by removing the essential habitant which encouraged their distribution and activity, as weeds and shelter of dead and dry weeds save the suitable substrate to these land snails and slugs, where protect them from natural enemies in addition to providing these pests with enough moisture and relative humidity. Tillage process was proceeded to remove these weeds and limiting the relative humidity according to reports of Godan, 1983, El-Okda, 1979 and Bishara, et al., 1986.

\section{A- Effect of tillage on M.theba. Cartisenia:}

Data obtained from Table 3 stated that tillage had a great effect in most tested samples which conducted at three districts of Damietta Governorate and the district of El-Dakahlia. There was no significant differences between reduction percentages of tillage and that of using Lanit 90 but in some sites was more effective than Lanit 90.

Fareskure district showed equal results for tillage and Lanit 90 under lemon trees, where the reduction percentage was $73 \%$ for both. While at ElZarka Lanit 90 was more effective (80\%) than first tillage $(66 \%)$ and second tillage (75\%) and also Kafr Saad district, had efficiency of Lanit 90 (76\%) more than first tillage and second tillage (70\%) and similar to Sheirben district of Dakahlia Governorate which presented equal effect with first and second tillage (69\%) less than Lanit $90(73 \%)$. 
J. Agric. Sci. Mansoura Univ., 34 (2), February, 2009

1 
Awad, M. H. and Y. Y. Ramaddan

2

1316 
J. Agric. Sci. Mansoura Univ., 34 (2), February, 2009

3 
Under orange trees, it was noticed that the reduction of individuals resulting from $(80 \%)$ was more effective than the second tillage $(71 \%)$ and Lanit $90(52 \%)$. Also, under guava trees, there was no difference between three tested treatments in each of Fareskure, El-Zarka and Sheirbein but at Kafr Saad there was significant variation between tillage and Lanit 90 since tillage was more effective $(80 \%$ and $83 \%)$ for first and second tillage, respectively but Lanit $90,73 \%$ reduction in peach reduction resulting from second tillage $75 \%$ more effective than that with first tillage (69\%) and Lanit $90(60 \%)$ the same result with Sherbien district and Kafr Saad in converse with El-Zarka district which showed that Lanit 90 was more effective $(67 \%)$ than in first tillage (31\%) and second tillage (49\%).

\section{B- Effect of tillage on $D$. reticulatum}

At Faraskour district the second tillage was more effective on $D$. reticulatum under lemon, orange and guava (92, 89, and $92 \%)$, respectively than the effect of Lanit 90 which represented $(89,82$, and $88 \%)$ on lemon, orange and guava similar to that of orange and guava at El-Zarka district which recorded 88, 91\% respectively. Also, in peach at Sherbien and Kafr Saad districts which recorded 82 and $81 \%$ respectively in converse with that in lemon and peach at El-Zarka 88 and $87 \%$ for Lanit 90 more effective than that with the first and second tillage 73 and $82 \%$, respectively.

\section{CONCLUSION}

From the previous results it can be concluded that the agricultural control could be throw some light on safe and healthy method, healthy for product, animal, plant, soil and human in addition its costs which was cheaper than pesticides in addition to increasing production quantity and quality through weed control and avoiding the great damage resulting from competition of these weeds to the main plant. Also, tillage destroyed pre hatched snails and egg clusters by mechanical effect and limiting soil moisture and relative humidity which is the essential factor for land snails and slugs' distribution and activity.

\section{REFERENCES}

Abott, W. S (1925). A method of computing the effectiveness of an insecticide J. Econ. Entomol., 18, 265-267.

Bishara, S. I, M. S Hassan and A.S. Kalliny (1968). Studies on some land snails injuries to agriculturare in U. A. R. Rev. Zool. Bot., Agric., Lxxvll (3-4): 239-252.

Coate. T. E.. Loeve (2003). From 61 specied to five, endemic tree snails of the society island fall prey to an ill-judged biological control program oryyx $37,91-96$.

Davison, A. and S. chibas (2006). The recent history and population structure of the mandarin snail species from sub-tropical ogasawara (Bonin Island-Japan) Molecular ecology 15 (10) 2950-2919. 
Duncan, J (1983). The biochemical and physiological basis of the mode of action of mollusciciddes "Plant molliscicides, E. M Kenneth,, Ed. John Willy of suns Ltd pp. 27-44

El-Okda, M. M. K (1979). Land snail of economic at Alexandria region with some notes on the morphological features, classification, economic damage and population on ornamental plant. Agric. Res. Rev., 57(1) 125-130.

El-Okda, M. M. K (1980). Land snail of economic importance on vegetable crops at Alexandria and night boring regions. Agric. Res. Rev., 58(1) 49-85.

El-Okda, M. M. K (1984). Land mollusca infestation and chemical control in El-Ismailia governorate. Agric. Res. Rev., 62(1) 87-92.

Ghamry, E. M., H. I, El-Deeb and H. Abdel-Aal (1993). Efficiency of certain pesticides against some land snails under field conditions of Sharkia governorate, Egypt. 3. Appl. Sci., 8(1) 764-774.

Godan, D(1983). Pest Slugs and Snails, Biological and Control Springer, Verlag, Berdin Heidelberger. New York.445pp

Hashiem, A, G., J. M. Nakhla, A.W. tadros and M. A. Korashy (1993). Monitoring land snails on sweet orange trees in Beheira governorate, Egypt. Zagazig J. Agric. Res. Vol. (20), 691-698.

Hendreson, G. F and E. W. Tilton (1955). Test with acaroids against the brown wheat mite J. Econ. Entermol., 48:157-161.

Kassab, A and H. Daoud (1964). Notes on the biological and control of economic importance land snails U. A. R. Agric. Res. Rev., (42):17-98.

Satoshi, C (2003). Species diversity and conservation of mandarin, an endemic land snail of the ogasawara Islands. Jp/ Publication/ Ger./ PDF/07101-04 PDF.

\section{استبدال طرق المكافحة الكيميائية بوسائل ميكانيكية كوسيلة صديقة للبيئة لمكافحة القواقع والبزاقات فى أشجار الثمار الفاكهة

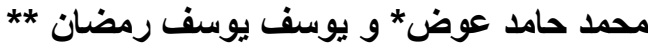

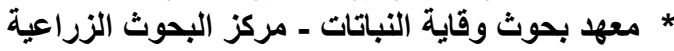

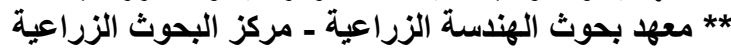

تنتمى القو اقع و البز اقات الأرضية إلى قبيلة الرخويات وهى عبات عبارة عن حيو انات ذات أجسام

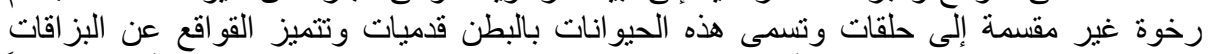

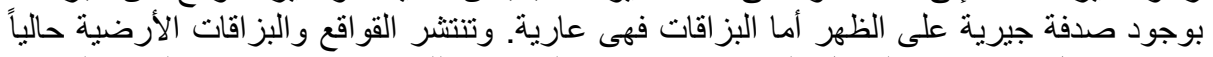

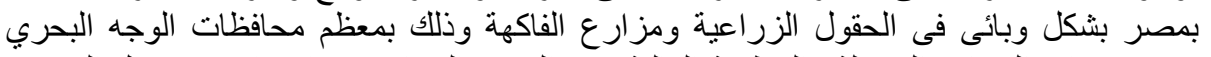

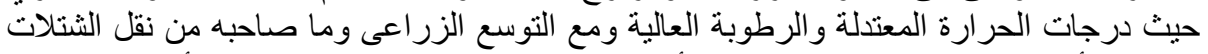

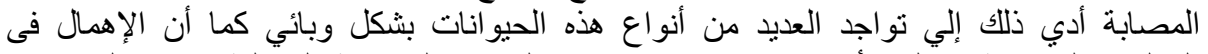

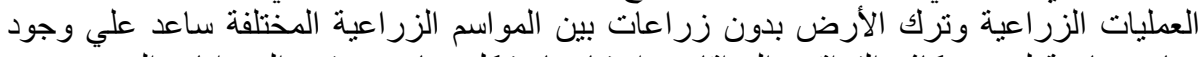

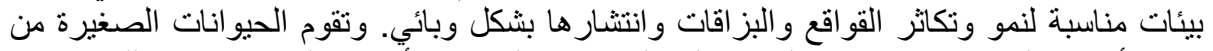

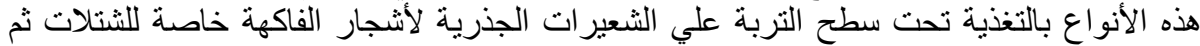

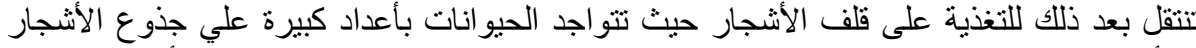
و الأفرع الجانبية متغذية علي القمم النامية ثم تنتقل بعد ذلك الإصابة بالقو اقع علي الأوراق و الثمار 


\section{Awad, M. H. and Y. Y. Ramaddan}

مما يؤدي إلي تساقطها كما أن قيام هذه الحيوانات بنشر الثمار يؤدي إلي تعرضها للإصابة

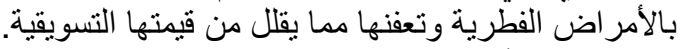

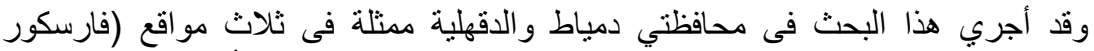

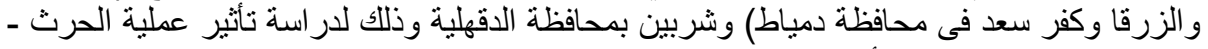

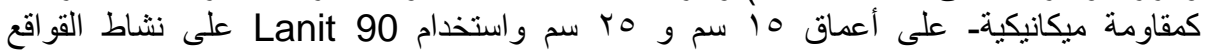

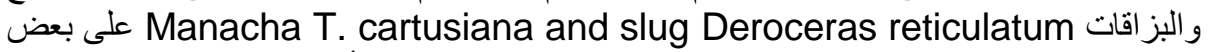
محاصيل الفاكهة (الليمون و البرتقال والجوافة والمشمش) بالمقارنة بأنشجار فاكهة لم يتم معاملتها

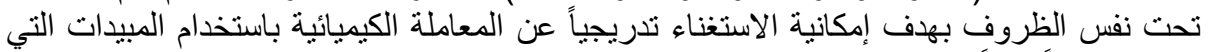

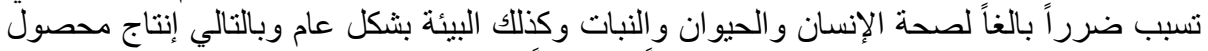

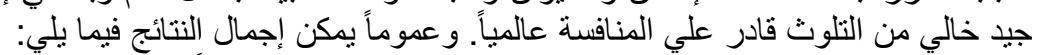

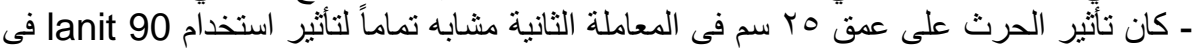

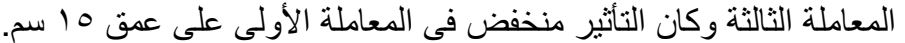

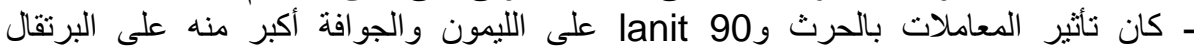

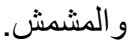

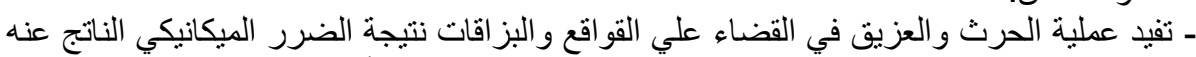

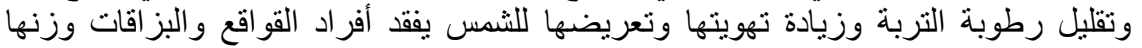

$$
\text { وقدرنها علي الحياة. }
$$

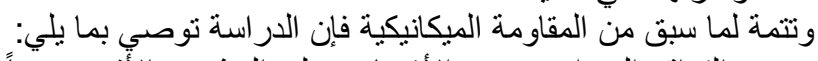

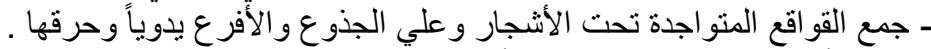

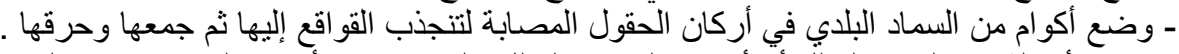

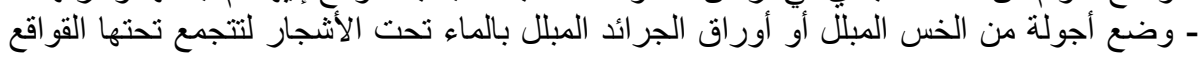

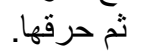

- وضع طعوم جذابة مثل خليط الردة و العسل 90,0 جز ه أو البطاطس أو البطاطا المسلوقة و هرسها

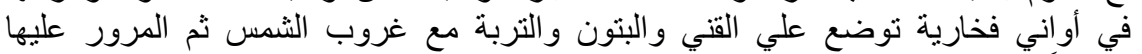
صباحاً لجمع القو اقع منها وحرقِّا. - حش البرسيم قبل غروب الثبمس ونتوزيعه علي هيئة أكوام صغيرة مع رفع هذه الأكوام في الصباح التالي وجمع القو اقع التي تحتها وحرقها. 
J. Agric. Sci. Mansoura Univ., 34 (2), February, 2009 

Table 1. Number of individuals of Monacha theba cartusiana and Deroceras reticulatum under fruit trees at Faraskoure, El-Zarka, Sherbien and Kafr-Saad ditructs through the two seasons of 2006.

\begin{tabular}{|c|c|c|c|c|c|c|c|c|c|c|c|c|c|c|c|c|c|c|c|}
\hline \multirow{3}{*}{\multicolumn{2}{|c|}{ Season }} & \multicolumn{16}{|c|}{ Number of individuals on } & \multirow{2}{*}{\multicolumn{2}{|c|}{ Climatic factors }} \\
\hline & & \multicolumn{4}{|c|}{ Lemon } & \multicolumn{4}{|c|}{ Orange } & \multicolumn{4}{|c|}{ Guava } & \multicolumn{4}{|c|}{ Peach } & & \\
\hline & & M. & D. & $\mathbf{T}$ & Mean & M. & D. & $\mathbf{T}$ & Mean & M. & D. & $T$ & Mean & M. & D. & $\mathbf{T}$ & Mean & $\mathbf{C}^{\circ}$ & $\mathbf{R H}, \%$ \\
\hline \multirow{2}{*}{ Fareskoure } & W & 36 & 30 & 66 & 33 & 30 & 24 & 54 & 27 & 36 & 34 & 70 & 35 & 24 & 22 & 46 & 23 & 18 & 58 \\
\hline & $S$ & 40 & 33 & 73 & 36.5 & 58 & 26 & 84 & 42 & 58 & 36 & 94 & 47 & 36 & 24 & 60 & 30 & 24 & 56 \\
\hline \multicolumn{2}{|l|}{ Total } & 76 & 63 & 139 & 69.5 & 88 & 50 & 138 & 66 & 94 & 70 & 164 & 82 & 60 & 46 & 106 & 53 & & \\
\hline \multicolumn{2}{|l|}{ Mean } & 38 & 31.5 & 69.5 & & 44 & 25 & 69 & & 27 & 35 & 82 & & 30 & 23 & 53 & & & \\
\hline \multirow{2}{*}{ El-Zarka } & W & 32 & 22 & 54 & 27 & 30 & 22 & 52 & 26 & 34 & 24 & 58 & 29 & 20 & 20 & 40 & 20 & 17 & 54 \\
\hline & $S$ & 38 & 24 & 62 & 31 & 48 & 24 & 72 & 36 & 48 & 26 & 58 & 29 & 44 & 26 & 70 & 35 & 26 & 56 \\
\hline \multicolumn{2}{|l|}{ Total } & 70 & 46 & 116 & 58 & 78 & 46 & 124 & 62 & 82 & 50 & 116 & 58 & 64 & 46 & 110 & 55 & & \\
\hline \multicolumn{2}{|l|}{ Mean } & 35 & 23 & 58 & & 39 & 23 & 62 & & 41 & 25 & 58 & & 32 & 23 & 55 & & & \\
\hline \multirow{2}{*}{ Sherbien } & W & 34 & 30 & 64 & 32 & 20 & 26 & 46 & 23 & 30 & 26 & 56 & 28 & 18 & 21 & 39 & 19.5 & 19 & 54 \\
\hline & $S$ & 52 & 34 & 86 & 43 & 44 & 28 & 72 & 36 & 58 & 28 & 84 & 42 & 45 & 26 & 71 & 35.5 & 26 & 58 \\
\hline \multicolumn{2}{|l|}{ Total } & 86 & 64 & 150 & 75 & 64 & 54 & 118 & 59 & 88 & 54 & 140 & 70 & 63 & 47.5 & 110 & 55 & & \\
\hline \multicolumn{2}{|l|}{ Mean } & 43 & 32 & 75 & & 32 & 72 & 59 & & 44 & 27 & 70 & & 31.5 & 23.5 & 55 & & & \\
\hline \multirow{2}{*}{ Kafr-Saad } & W & 28 & 20 & 48 & 24 & 24 & 18 & 42 & 21 & 26 & 20 & 46 & 23 & 22 & 20 & 42 & 21 & 19 & 56 \\
\hline & $S$ & 46 & 24 & 70 & 35 & 48 & 21 & 69 & 34.5 & 50 & 22 & 72 & 36 & 46 & 22 & 68 & 34 & 28 & 58 \\
\hline \multicolumn{2}{|l|}{ Total } & 74 & 44 & 118 & 59 & 72 & 39 & 111 & 55.5 & 68 & 42 & 110 & 55 & 68 & 42 & 110 & 55 & & \\
\hline \multicolumn{2}{|l|}{ Mean } & 37 & 22 & 59 & & 36 & 19.5 & 55.5 & & 34 & 21 & 55 & & 34 & 21 & 55 & & & \\
\hline
\end{tabular}

LSD 5\% $=4.46$

$\mathrm{M}=$ Monacha theba cartusiana

$=$ Deroceras reticulatum

\begin{tabular}{l|l|l|}
\hline 34 & 21 & 55 \\
\hline
\end{tabular} Sp. = Spring 
Awad, M. H. and Y. Y. Ramaddan

Table 2. Effect of tillage process on Manacha T. Cartusiana and Deroceras reticulatum under fruit trees at Fareskoure, El-Zarka, and Kafr-Saad ditructs of Damietta Governorate and Sherbien district of ElDakahlia Governorate

Key words, Site $1=$ treated by tillage one way with depth of $15 \mathrm{~cm}$, Site $2=$ treated by tillage two way with depth of $25 \mathrm{~cm}$ and Site $3=$ treated by Lanit 90 .

Re duction, $\%=\frac{\text { untreated }- \text { treated }}{\text { untreated }} \times 100$ and corrected by Abott, 1925 
Table 3. Effect of tillage process on Manacha theba. cartusiana and Deroceras reticulatum under fruit trees at Fareskoure,El-Zarka, and Kafr-Saad districts of Damietta Governorate and Sherbien district of ElDakahlia Governorate.

\begin{tabular}{|c|c|c|c|c|c|c|c|c|c|c|c|c|c|c|c|c|c|}
\hline \multirow{4}{*}{ District } & \multirow{4}{*}{ Sites } & \multicolumn{16}{|c|}{ Number of affected individuals on } \\
\hline & & \multicolumn{8}{|c|}{ M. theba. cartusana } & \multicolumn{8}{|c|}{ D. reticulatum } \\
\hline & & \multicolumn{2}{|c|}{ lemon } & \multicolumn{2}{|c|}{ orange } & \multicolumn{2}{|c|}{ Guava } & \multicolumn{2}{|c|}{ peach } & \multicolumn{2}{|c|}{ lemon } & \multicolumn{2}{|c|}{ orange } & \multicolumn{2}{|c|}{ guava } & \multicolumn{2}{|c|}{ peach } \\
\hline & & No. & Red.\% & No. & Red.\% & No. & Red.\% & No. & Red.\% & No. & Red.\% & No. & Red.\% & No. & Red.\% & No. & Red.\% \\
\hline \multirow{3}{*}{$\begin{array}{l}\text { Faras- } \\
\text { kour }\end{array}$} & Site1 & 27.6 & $73 \mathrm{AB}$ & 22.0 & $73 \mathrm{~B}$ & 33.6 & $70 \mathrm{C}$ & 11.6 & $64 \mathrm{C}$ & 22.0 & $79 \mathrm{C}$ & 18.4 & $77 \mathrm{D}$ & 30.6 & $86 \mathrm{AB}$ & 18.0 & $75 \mathrm{BC}$ \\
\hline & Site2 & 29.2 & $73 \mathrm{AB}$ & 23.6 & $74 \mathrm{~B}$ & 36.8 & 68CD & 18.0 & $75 \mathrm{~A}$ & 30.2 & $92 \mathrm{~A}$ & 23.0 & $89 \mathrm{~A}$ & 31.4 & $92 \mathrm{~A}$ & 15.2 & $84 \mathrm{~B}$ \\
\hline & Site3 & 26.4 & $73 \mathrm{AB}$ & 20.0 & $71 \mathrm{BC}$ & 29.8 & $71 \mathrm{C}$ & 13.2 & $60 \mathrm{C}$ & 26.6 & $89 \mathrm{AB}$ & 19.6 & $82 \mathrm{BC}$ & 30.0 & $88 \mathrm{AB}$ & 18.6 & $85 \mathrm{~B}$ \\
\hline \multirow{3}{*}{ El-Zarka } & Site1 & 21.2 & $66 \mathrm{D}$ & 17.6 & $80 \mathrm{~A}$ & 31.0 & $74 \mathrm{~B}$ & 5.00 & $31 \mathrm{~F}$ & 13.8 & $77 \mathrm{C}$ & 15.0 & $83 \mathrm{BC}$ & 19.4 & $89 \mathrm{AB}$ & 18.4 & $77 \mathrm{BC}$ \\
\hline & Site2 & 28.4 & $75 \mathrm{~B}$ & 20.0 & $71 \mathrm{BC}$ & 41.0 & $79 \mathrm{~B}$ & 10.8 & $49 \mathrm{E}$ & 16.0 & 73CD & 16.0 & $88 \mathrm{~A}$ & 23.6 & $91 \mathrm{~A}$ & 18.0 & $82 \mathrm{~B}$ \\
\hline & Site3 & 28.8 & $80 \mathrm{~A}$ & 10.4 & $52 \mathrm{D}$ & 28.8 & $72 \mathrm{BC}$ & 17.4 & $67 \mathrm{BC}$ & 16.0 & $88 \mathrm{~B}$ & 16.2 & $85 \mathrm{~B}$ & 21.2 & $88 \mathrm{AB}$ & 22.4 & $87 \mathrm{~A}$ \\
\hline \multirow{3}{*}{$\begin{array}{l}\text { Sher- } \\
\text { bien }\end{array}$} & Site1 & 23.4 & $69 \mathrm{C}$ & 15.2 & $63 \mathrm{C}$ & 21.0 & $66 \mathrm{C}$ & 14.0 & $58 \mathrm{D}$ & 25.2 & $79 \mathrm{BC}$ & 22.2 & $86 \mathrm{~B}$ & 21.6 & $83 \mathrm{BC}$ & 18.6 & $77 \mathrm{BC}$ \\
\hline & Site2 & 28.8 & $69 \mathrm{C}$ & 20.4 & $64 \mathrm{C}$ & 30.0 & $75 \mathrm{~B}$ & 21.0 & $75 \mathrm{~A}$ & 28.2 & $83 \mathrm{C}$ & 24.8 & $81 \mathrm{C}$ & 24.6 & $88 \mathrm{AB}$ & 21.2 & $82 \mathrm{~B}$ \\
\hline & Site3 & 27.8 & $73 \mathrm{~B}$ & 17.6 & $62 \mathrm{C}$ & 24.4 & 68CD & 14.4 & $60 \mathrm{C}$ & 25.8 & $81 \mathrm{C}$ & 21.8 & $81 \mathrm{C}$ & 23.4 & $87 \mathrm{AB}$ & 18.4 & $77 \mathrm{BC}$ \\
\hline \multirow{3}{*}{$\begin{array}{l}\text { Kafr } \\
\text { Saad }\end{array}$} & Site1 & 26.4 & $70 \mathrm{BC}$ & 34.4 & $75 \mathrm{~B}$ & 30.4 & $80 \mathrm{~A}$ & 15.6 & 71B & 14.8 & $74 \mathrm{D}$ & 13.0 & $81 \mathrm{C}$ & 12.0 & $75 \mathrm{C}$ & 14.2 & $71 \mathrm{D}$ \\
\hline & Site2 & 29.2 & $70 \mathrm{BC}$ & 34.0 & $71 \mathrm{BC}$ & 34.8 & $83 \mathrm{~A}$ & 18.8 & $72 \mathrm{~B}$ & 14.2 & $79 \mathrm{C}$ & 15.4 & $86 \mathrm{~B}$ & 13.8 & $77 \mathrm{C}$ & 17.0 & $81 \mathrm{~B}$ \\
\hline & Site3 & 27.2 & $76 \mathrm{~A}$ & 29.0 & $74 \mathrm{~B}$ & 26.4 & $73 \mathrm{BC}$ & 14.2 & $59 \mathrm{C}$ & 18.0 & $82 \mathrm{C}$ & 18.2 & $90 \mathrm{~A}$ & 15.4 & $77 \mathrm{C}$ & 17.2 & $78 \mathrm{BC}$ \\
\hline
\end{tabular}


Awad, M. H. and Y. Y. Ramaddan 